\title{
Fuzzy Inference System pada Produksi Kerupuk Mie Bulat
}

\author{
Windah Sahara1, Ega Widya Sari², Putri Mai Sarah Tarigan ${ }^{3}$ \\ STIKOM Tunas Bangsa Pematangsiantar \\ Jl. Sudirman Blok A No. 1-3 Pematangsiantar \\ windasahara456@gmail.com,egawidia8@gmail.com,tariganputri11@gmail.com
}

\begin{abstract}
Raw material processing business is a business that manages raw materials into finished or semi-finished materials. At present, the effort to defeat the raw material that is in great demand by people is the business of processing raw materials that produce food products such as bread, tempeh, tofu, noodles, crackers which have become public consumption in general. For example, crackers that have a variety of flavors and shapes. One of them is round noodle crackers that we have met in many daily lives and are often consumed by the community. CV. Hariarado is one of the producers of round noodle crackers. Where CV. Hariarado has not been able to determine production on a weekly basis due to uncertain demand. So this study aims to predict the amount of production produced by $C V$. Hariarado on a weekly basis. This study uses three variables, namely demand (X), inventory $(Y)$, and production (Z). The results of the calculation show that the prediction of the amount of production produced by CV. Hariarado with the demand of 950 ball and the supply of 1250 balls in a week is 1039 ball.
\end{abstract}

Keywords: round noodle crackers, business, fuzzy, tsukamoto, CV.Hariarado

Abstrak- Usaha pengolahan bahan baku adalah usaha yang mengelola bahan mentah menjadi bahan jadi maupun setengah jadi. Pada masa kini, usaha pengolalahan bahan baku yang banyak diminati oleh orang adalah usaha pengolahan bahan baku yang menghasilkan produk pangan seperti roti, tempe, tahu, mie, kerupuk yang sudah menjadi konsumsi masyarakat pada umumnya. Misalnya saja kerupuk yang memiliki berbagai macam rasa maupun bentuk. Salah satunya adalah kerupuk mie bulat yang sudah banyak kita jumpa pada kehidupan sehari-hari dan sering dikonsumsi masyrakat. CV.Hariarado adalah salah satu produsen dari produksi kerupuk mie bulat. Di mana CV.Hariarado belum mampu menentukan produksi pada setiap minggunya karena permintaan yang tidak menentu. Maka penelitian ini bertujuan untuk memprediksi jumlah produksi yang dihasilkan oleh CV.Hariarado pada setiap minggunya. Penelitian ini menggunakan tiga variabel yaitu permintaan $(\mathrm{X})$, persediaan $(\mathrm{Y})$, dan produksi $(\mathrm{Z})$. Hasil dari perhitungan menunjukkan bahwa prediksi jumlah produksi yang dihasilkan oleh CV.Hariarado dengan permintaan 950 ball dan persedian 1250 ball dalam seminggu adalah 1039 ball.

Kata kunci: kerupuk mie bulat, usaha, fuzzy, tsukamoto, CV.Hariarado

\section{PENDAHULUAN}

Usaha pengolahan bahan baku adalah usaha yang mengelola bahan mentah menjadi bahan jadi atau bahan setengah jadi. Pada masa ini, usaha pengolahan bahan baku yang banyak diminati adalah usaha pengolahan bahan baku yang menghasilkan produk pangan. Produk pangan sendiri dapat berupa roti, tempe, tahu, mie, maupun kerupuk. Di mana, masyarakat sudah banyak mengkonsumsi beberapa produk pangan tersebut. Misalnya saja kerupuk. Kerupuk memiliki 
beraneka ragam nama, rasa, maupun bentuk. Jenis kerupuk yang sering ditemui yaitu kerupuk mie bulat. Kerupuk mie bulat memiliki ciri khas yang unik yakni berbentuk mie yang disusun secara melingkar dan berwarna kuning. Namun, bukan hanya ciri khas-nya saja yang unik, tetapi juga cita rasa dari kerupuk itu sendiri yang membuat kerupuk mie bulat ini laris di pasaran.

CV. Hariarado adalah sebuah usaha yang bergerak dalam bidang pengolahan bahan baku yang menghasilkan suatu produk pangan yang berdiri pada tahun 2009. CV. Hariarado terletak di Pematangsiantar, tepatnya di Jln. Medan km 7. Produk yang di hasilkan oleh CV. Hariarado yaitu berupa kerupuk mie bulat. Kerupuk ini sering kita jumpai di kedai maupun warung, sebab kerupuk ini cocok untuk dijadikan lauk maupun cemilan. Permintaan yang tidak menentu mengakibatkan CV.Hariarado kesulitan dalam menentukan jumlah produksi yang dihasilkan pada setiap minggunya. Berdasarkan permasalahan di atas, dibutuhkan sebuah sistem prediksi untuk menentukan jumlah produksi kerupuk mie bulat pada CV. Hariarado. Dan untuk menyelesaikan permasalahan di atas, peneliti menggunakan metode fuzzy tsukamoto. Metode ini dipilih karena mempunyai aturan berbentuk IF-THEN yang akan dipresentasikan dalam himpunan fuzzy dengan fungsi keanggotaan yang monoton.[1]

\section{METODOLOGI PENELITIAN}

\subsection{Logika Fuzzy}

Logika fuzzy merupakan sebuah logika yang memiliki nilai kekaburan atau kesamaran (fuzzyness) antara benar dan salah [2]. Dalam teori logika fuzzy sebuah nilai bisa bernilai benar atau salah secara bersamaan namun berapa besar kebenaran dan kesalahan suatu nilai tergantung kepada bobot keanggotaan yang dimilikinya. [3] Dalam logika fuzzy kemungkinan nilai keanggotaan berada diantara 0 dan 1.[4]

\subsection{Metode Tsukamoto}

Pada metode tsukamoto, setiap konsekuen pada aturan yang berbentuk IFTHEN harus direpresentasikan dengan suatu himpunan fuzzy dengan fungsi keanggotaan yang monoton. Output hasil inferensi dari tiap-tiap aturan diberikan secara tegas (crisp) berdasarkan $\alpha$-predikat (fire strength). Hasil akhirnya diperoleh dengan menggunakan rata-rata terbobot.[5]

a. Fuzzifikasi adalah proses yang dilakukan untuk mengubah variabel nyata menjadi variabel fuzzy.[6]

b. Pembentukan fuzzy rule dalam bentuk IF.....THEN.

c. Perhitungan untuk mencari $\alpha$-predikat dengan menggunakan fungsi implikasi yaitu MIN dengan rumus:

$\alpha$-predikat $=\min \left[\mu_{a}(\mathrm{x}) ; \mu_{b}(\mathrm{y})\right] \quad(1)$

d. Defuzzyfikasi adalah proses yang digunakan untuk mengubah kembali variabel fuzzy menjadi variabel nyata dengan rumus:

$\mathrm{Z}=\frac{\alpha-\text { predikat }_{1} * Z_{1}+\alpha-\text { predikat }_{2} * Z_{2}+\cdots+\left(\alpha-\text { predikat }_{n} * Z_{n}\right)}{\alpha-\text { predikat }_{1}+\alpha-\text { predikat }_{2}+\cdots+\left(\alpha-\text { predikat }_{n}\right)}$ 


\section{HASIL DAN PEMBAHASAN}

CV. Hariarado memiliki data satu minggu terakhir. Di mana permintaan terbesar mencapai 1000 ball, sedangkan permintaan terkecil mencapai 700 ball. Sementara persediaan di gudang paling banyak adalah 2000 ball dan paling sedikit adalah 1000 ball. Dengan segala keterbatasan, CV. Hariarado hanya mampu memproduksi barang maksimal 1200 ball dan paling sedikit 700 ball. Berapakah produksi yang harus dihasilkan dalam seminggu jika permintaan 950 ball dan persediaan 1250 ball?

Langkah-langkahnya yaitu:

a. Fuzzyfikasi

Terdapat 3 variabel yang akan dimodelkan menggunakan fungsi keanggotaan representasi linier, yaitu:

1. Permintaan

Fungsi keanggotaan yang digunakan yaitu himpunan Turun, Naik dari variabel

Permintaan:

$\mu X[$ Turun $]=\left\{\begin{array}{cc}1 & x<700 \\ \frac{1000-x}{1000-700} & 700<x<1000 \\ 0 & x>1000\end{array}\right.$

$\mu X[$ Naik $]=\left\{\begin{array}{cc}0 & x>1000 \\ \frac{x-700}{1000-700} & 700<x<1000 \\ 1 & x<700\end{array}\right.$

Nilai keanggotaan himpunan turun dan naik dari variabel permintaaan:

$\mu x \operatorname{Turun}(950)=(1000-950) / 300$

$=0,166666667$

$\mu x \operatorname{Naik}(950)=(950-700) / 300$

$=0,833333333$

2. Persediaan

Fungsi keanggotaan yang digunakan yaitu himpunan Sedikit, Banyak dari variabel Persediaan:

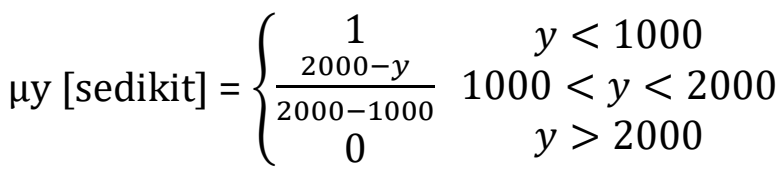

$\mu y[$ banyak $]=\left\{\begin{array}{cc}0 & y>2000 \\ \frac{y-1000}{2000-1000} & 1000<y<2000 \\ 1 & y<1000\end{array}\right.$

Nilai keanggotaan himpunan sedikit dan banyak dari variabel persediaan: 
$\mu y$ Sedikit(1250) $=(2000-1250) / 1000$

$$
=0,25
$$

$\mu y \operatorname{Banyak}(1250)=(1250-1000) / 1000$

$$
=0,75
$$

3. Produksi

Fungsi keanggotaan yang digunakan yaitu himpunan Sedikit, Banyak dari variabel Persediaan:

$\mu \mathrm{z}$ [bertambah] $=\left\{\begin{array}{cc}0 & z>1200 \\ \frac{z-700}{1200-700} & 700<z<1200 \\ 1 & z<700\end{array}\right.$

$\mu \mathrm{z}$ [berkurang] $=\left\{\begin{array}{cc}1 & z<700 \\ \frac{1200-z}{1200-700} & 700<z<1200 \\ 0 & z>1200\end{array}\right.$

b. Pembentukan Fuzzy Rule

Pada pembentukan fuzzy rule, penulis menggunakan 4 aturan fuzzy yang ditunjukkan pada tabel 1.

Tabel 1. Fuzzy Rule

\begin{tabular}{|c|c|c|c|}
\hline Rule & Permintaan & Persediaan & Produksi \\
\hline 1 & Turun & Banyak & Berkurang \\
\hline 2 & Turun & Sedikit & Berkurang \\
\hline 3 & Naik & Banyak & Bertambah \\
\hline 4 & Naik & Sedikit & Bertambah \\
\hline
\end{tabular}

c. Perhitungan untuk mencari nilai dari $\alpha$ - predikat yaitu:

Rule 1:

$\alpha$-predikat $\quad=\min (0,166666667 ; 0,25)$

$\mathrm{Z} \quad=0,166666667$

$0,166666667=\frac{1200-x}{500}$

$1200-\mathrm{x}=0,166666667 \times 500$

$1200-\mathrm{x} \quad=83.33333333$

$-\mathrm{X} \quad=83.33333333-1200$

$-\mathrm{X} \quad=-1117$

$\mathrm{X} \quad=1117$

Rule 2:

$\alpha$-predikat $\quad=\min (0,166666667 ; 0,75)$

$\mathrm{Z} \quad=0,166666667$

$0,166666667=\frac{1200-x}{500}$

$1200-\mathrm{x}=0,166666667 \times 500$

$1200-\mathrm{x} \quad=83.33333333$

$-\mathrm{X} \quad=83.33333333-1200$ 


$$
\begin{array}{ll}
-\mathrm{X} & =-1117 \\
\mathrm{X} & =1117
\end{array}
$$

Rule 3:

$\alpha$-predikat $\quad=\min (0,833333333 ; 0,25)$

$\mathrm{Z} \quad=0,25$

$0,25 \quad=\frac{x-700}{500}$

$\mathrm{x}-700 \quad=0,25 \times 500$

$\mathrm{x}-700 \quad=125$

$\mathrm{x} \quad=125+700$

$\mathrm{X} \quad=825$

Rule 4:

$\alpha$-predikat $\quad=\min (0,833333333 ; 0,75)$

$\mathrm{Z} \quad=0,75$

$0,75 \quad=\frac{x-700}{500}$

$\mathrm{x}-700 \quad=0,75 \times 500$

$\mathrm{x}-700 \quad=375$

$\mathrm{x} \quad=375+700$

$\mathrm{x} \quad=1075$

d. DeFuzzyFikasi

$$
\begin{aligned}
Z & =\frac{(0,167 \times 1117)+(0,167 \times 1117)+(0,25 \times 825)+(0,75 \times 1075)}{0,167+0,167+0,25+0,75} \\
& =\frac{186.1666667+186.1666667+206.25+806.25}{1.333333333} \\
& =\frac{1384.833333}{1.333333333} \\
& =1039
\end{aligned}
$$

Jadi, menurut perhitungan di atas dapat disimpulkan bahwa produksi yang dapat dihasilkan oleh CV. Hariarado dalam seminggu adalah 1039 ball.

\section{KESIMPULAN}

Berdasarkan pembahasan di atas mengenai Metode Fuzzy Tsukamoto dalam menentukan jumlah produksi perminggu di CV. Hariarado dapat dilakukan dengan menggunakan tiga variabel yaitu permintaan, persediaan, dan produksi. Dari hasil perhitungan yang telah dilakukan maka dapat diprediksi bahwa produksi yang harus dihasilkan dalam seminggu oleh CV. Hariarado jika permintaan 950 ball dan persediaan 1250 ball adalah 1039 ball. Dengan hasil ini maka dapat mempermudah CV. Hariarado dalam memprediksi produksi yang dapat dihasilkan dalam seminggu.

\section{DAFTAR PUSTAKA}

[1] A. Mulyanto, A. Haris, A. Best, B. Indonesia, and A. Bekasi, "Penerapan Metode Fuzzy Tsukamoto Untuk Menentukan Jumlah Jam Overtime Pada Produksi Barang di PT Asahi Best 
Base Indonesia ( ABBI ) Bekasi Abstrak," vol. 1, no. 1, pp. 1-11, 2016.

[2] A. Wanto, "Analisis Penerapan Fuzzy Inference System (FIS) Dengan Metode Mamdani Pada Sistem Prediksi Mahasiswa Non Aktif (Studi Kasus : AMIK Tunas Bangsa Pematangsiantar)," in Seminar Nasional Inovasi Dan Teknologi Informasi (SNITI) 3, 2016, vol. 3, pp. 393-400.

[3] S. Wibowo, "Penerapan Logika Fuzzy Dalam Penjadwalan Waktu Kuliah."

[4] I. Fakultas, "Fuzzy Inference System ( FIS ) dengan Metode Tsukamoto dan Mamdani dalam Menentukan Kelayakan Kenaikan Gaji Karyawan," vol. 1, no. 2, pp. 7-14, 2017.

[5] K. Harefa, T. Informatika, U. Pamulang, and L. Belakang, "PENERAPAN FUZZY INFERENCE SYSTEM UNTUK MENENTUKAN JUMLAH," vol. 2, no. 4, 2017.

[6] F. Tsukamoto and I. Pendahuluan, "IMPLEMENTASI ALGORITMA FUZZY TSUKAMOTO UNTUK MENENTUKAN JUMLAH PRODUKSI ROTI," pp. 23-29. 